(RESEARCH ARTICLE)

\title{
Gastrointestinal helminths of slaughtered cattle in Bauchi Central Abattoir, Bauchi State, Nigeria
}

\author{
Yuguda Amina Umar *, Samaila Adamu Babayo and Panda Sam Mao \\ Department of Biological Science, Abubakar Tafawa Balewa University, Bauchi, Nigeria.
}

Publication history: Received on 11 May 2018; revised on 30 July 2018; accepted on 16 August 2018

Article DOI: https://doi.org/10.30574/gscbps.2018.4.2.0036

\begin{abstract}
Cattle are major source of animal protein, flexible income for family units, employment, farm energy and manure but the problem is infection due to gastrointestinal helminths. The disease causes a gradual deterioration of animal performance and has been known to be major economic losses in Nigeria. Sedimentation and floatation parasitological techniques were used and examined microscopically to determine the parasites and the number of egg per gram of faeces. Of the 300 faecal sample examined, 223(74.3\%) were infected with one or more of the following species and their prevalence were three trematodes (Fasciola 15.7\%, Schistosome 6.0\%, Dicrocilium 1.6\%), three cestodes (Monezia 6.3\%, Taenia 8.0\%, Hymenolepis 2.0\%) and seven species of nematodes (Ascaris 3.3\%, Trichuris 1.0\%, Nematodirus 6.3\%, Haemonchus 9.3\%, Strongyloides 5.7\%, Toxocara 3.3\%, Ostertagia 5.0\%). Modified Stoll's dilution egg counting technique of 223 animals indicated, 74 animals (33.1\%) and 49 animals (21.9) were found with low and high infection level respectively, whilst greater proportion, 100 animals (44.8) were found with moderate number of egg per gram of faeces (egg) suggesting that the infection was moderately high. The breeds had a prevalence of $74.8 \%$, $72.3 \%$, and $70.0 \%$ obtained for Bunaji, Rohaji, and Sokoto Gudali cattle respectively. Higher prevalence of gastro intestinal parasites was observed in young cattle $<2$ years $(77.1 \%)$ and 3-5 years $(74.2 \%)$ than $>5$ years of age (70.58\%). This study reveals that both the male and female animals have equal likelihood of being infected with gastrointestinal helminths. Therefore, farmer awareness, and modern methods of rearing and caring for animals towards maximum productivity is advocated and should be encouraged through the Ministry of Agriculture.
\end{abstract}

Keywords: Gastrointestinal helminths; Prevalence; Parasites; Faeces; Cattle

\section{Introduction}

Nigeria had a mean cattle population of 13.9 million as at 1990 of which 11.5 million of this population were kept under pastoral system [1] and 2.4 million in the villages [2]. In Nigeria, the livestock sector contributes $5.2 \%$ of the gross domestic products (GDP) while cattle production solely contributes 50\% of the total Meat [3]. Meat is one of the most important livestock products, although there could be losses due to various diseases including helminth infections. The quantity of meat and revenue obtained from domestic livestock is far below the national demand due to factors such as death and ill health with associated reduced productivity and increased cost of treatment [4].

Helminths are known to be a major constraint to ruminant's well-being and productive performance [5]. Infections with helminthes parasites especially those of gastrointestinal tract (GIT) can and in some circumstance do cause substantial losses to cattle owners. The disease causes a gradual deterioration of animal performance and has been known to be major economic losses in the tropics and in Nigeria [6-7].

\footnotetext{
${ }^{*}$ Corresponding author

E-mail address: aminayuguda080@gmail.com
}

Copyright (C) 2018 Author(s) retain the copyright of this article. This article is published under the terms of the Creative Commons Attribution Liscense 4.0. 
The effect of the disease range from decreased utilization of feeds in unthrifty animals to weights loss or even death [8], [9]. Symptoms include loss of weight, poor growth, unthriftiness and a marked decreased in milk production, gut damage, blood loss, and anemia. Among the gastrointestinal parasites, nematodes present the greatest potential problems of which barber pole worm (Haemonchus spp) is the most important [10].

Gastrointestinal helminths are well spread in Nigeria [11] and are known to cause disease in ruminants which are of great economic importance. In cattle, this leads to decreased in protein production in terms of quantity and quality of milk, meat, dairy product, wool and damage to hide and skin. In Nigeria, the prevalence of helminthiasis infections varies from place to place and shows seasonal fluctuations [12] which may result to poor timing of control measures. Therefore, periodical comprehensive studies are required to know the level of gastrointestinal helminths in cattle slaughtered in Bauchi central abattoir and factors contributing to their prevalence and incidence.

\section{Material and methods}

\subsection{Description of the study area}

Bauchi state is located between latitude $10^{\circ} 18^{\prime} 57^{\prime \prime} \mathrm{N}$ and $09^{\circ} 50^{\prime} 39^{\prime \prime E}$, with a total area of $549,200 \mathrm{~km}^{2}$. The state is dry and hot in the north, while the southern part is milder. The rainfall starts in April to October in the southern part, while in the extreme north rains start from late June to September.

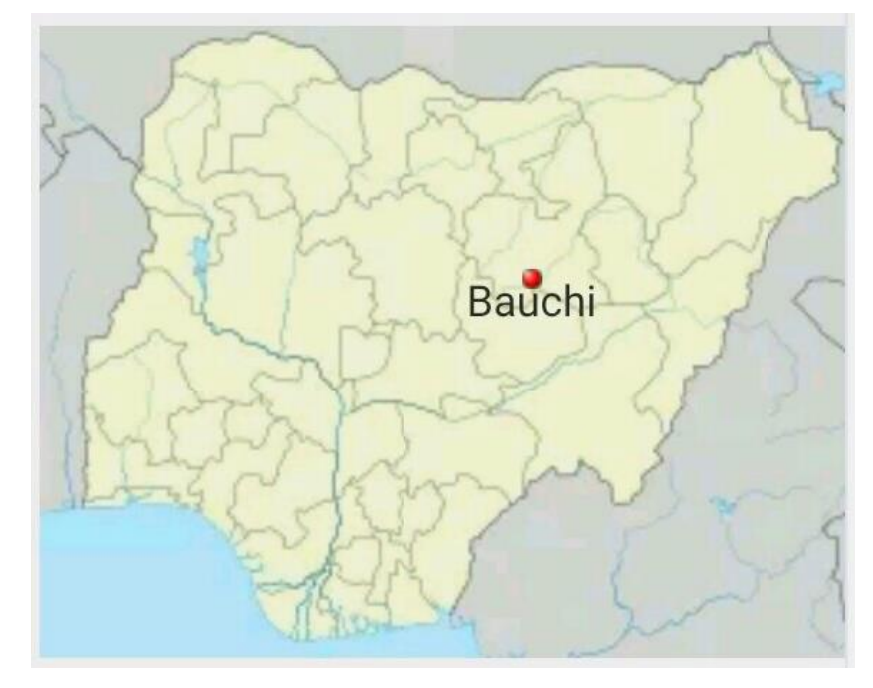

Figure 1 Map of the study area

\subsection{Sample size}

The sample size was calculated according to the formula given by using $95 \%$ level of confidence and expected prevalence was $76.7 \%$ from previous study of [13] and desired absolute precision of $5 \%$.

\subsection{Sample collection}

Prior to sample collection, visit was done to the abattoir so as to make preliminary arrangement towards collection of samples. Faecal samples were collected as early as 6:00-8:00 am weekly during the study period when the animals are taken to the abbatoir. The size, age, breed and site of sample from the animals were properly recorded. A total of 300 faecal samples were collected from August - January 2017. The samples were collected directly from the rectum and intestines of the slaughtered cattle using a pair of hand gloves into a cleaned labeled sterile specimen bottle. They were kept in an ice box and transported to biological science laboratory of Abubakar Tafawa Balewa University Bauchi for macroscopic and microscopic examination. Those that were not examined on that time were stored in refrigerator at 4 ${ }^{\circ} \mathrm{C}$. 


\subsection{Parasitological examination}

\subsubsection{Macroscopic}

The faecal samples were examined macroscopically for their consistency (water content) as watery, loose, and soft or formed and then categorized as either diarrheic or non-diarrheic.

\subsubsection{Microscopic}

Collected faecal materials were subjected to formal-ether technique [14-15] and Zinc sulphate flotation technique [16].

\subsection{Formal-ether concentration technique}

A gram of stool sample was emulsified with $4 \mathrm{ml}$ of $10 \%$ formal saline in a test tube. The mixture was filtered into a test tube using a cloth gauge and 3-4 ml of diethylether was added, shake vigorously and allowed to stand for two minutes. The mixture was then centrifuged at 1000 revolutions per minutes $(1000 \mathrm{rpm})$ for 3 minutes. Using a glass rod, the faecal debris from the side of the tube was loosened and the tube inverted to pour off the supernatants. The tube was returned to its original upright position and the fluid from the side of tube allowed drain to the bottom. The deposit was mixed by tapping the tube with the finger and using a Pasteur pipette. A drop of sediment was applied on microscope slide, covered with a cover slip and examined under the microscope using x10 and x40 objectives [14-15]. Lugol's iodine was used as a stain.

\subsection{Zinc sulphate floatation technique}

Three grams of faecal sample was mixed with $50 \mathrm{ml}$ of $0.4 \mathrm{~g} / \mathrm{ml}$ zinc sulphate (floatation fluids) in a dish container. The resulting faecal suspension was poured through a tea strainer into a centrifuge tube and centrifuged at 1500 revolution per minute (rpm) for 10 minutes. The centrifuge tube was then filled to the brim with more zinc sulphate and cover slip placed on top of the tube and allowed to stand for 20 minutes. The cover slip was removed from the centrifuge tube and placed on a glass slide for microscopic examination [16].

\subsection{Parasite count/load}

Faecal samples were subjected to Stoll's technique for counting helminths egg [14] and the degree of infection was identified based on total egg count per gram of faeces (epg) $[15,17]$. The animals were then categorized as low (100$250 \mathrm{epg}$ ), moderate (250-500 epg) and high (>500 epg) according to their egg per gram (EPG) of faces counts [16-17].

\subsection{Modified Stoll's dilution technique}

The technique is used to determine the total egg count per gram of faeces (epg) as described by [16]. The technique was carried out by mixing the faecal sample and then 3 grams of faeces were weighed with the help of a balance and put in $100 \mathrm{ml}$ graduated beaker. The beaker was then filled with water up to $42 \mathrm{ml}$ mark and the faeces were thoroughly mixed with water by magnetic stirrer. The mixture was then strained with a coffee strainer. The strained mixture was again shaken and $0.15 \mathrm{ml}$ of mixture was taken with a $1 \mathrm{ml}$ special pipette and put on a glass slide and covered with a cover slide. Care was taken to avoid bubble formation. The slide was then placed under a microscope and the eggs were identified and counted. The total number of eggs of parasites found in the slide was multiplied by 100 to get the eggs per gram of faeces (epg).

\subsection{Identification of organism}

The organisms observed were identified based on the morphological characteristics using the standard keys [18].

\subsection{Statistical analysis}

Descriptive statistics was used to determine the prevalence, and Chi-square analysis was employed to test the presence of variation between breed, age, sex involved in the study.

\section{Results and discussion}

\subsection{Prevalence and intensity of gastrointestinal helminths infection}

In all, 300 faecal samples of cattle were examined and 223(74.3\%) were positive for gastro intestinal helminth eggs. Several helminths were observed which include three Trematodes (Fasciola gigantica, Shistosoma bovis, and Dicrocilium dendriticum), three Cestodes (Monezia expansa, Taenia spp, Hymenolepis dimunuta) and seven Nematodes (Ascaris 
lumbricoides, Haemonchus spp, Trichuris spp, Nematodirus spp, Strongyloides spp, Toxocara vitoloruri and Ostertagia ostertagia).The prevalence of all identified parasitic helminth eggs (Table1) showed that faciola eggs had the highest prevalence and Trichuris present the latest occurrence group. The degree of helminths infection was determined from the total faecal egg count. The range of egg count per gram of faeces indicated 74 (33.1\%) with (epg 100-250) had low infection, $100(44.8 \%)$ with (epg250 - 500) were moderately affected and 49 (21.9\%) with (epg> 500) showed high intensity of infection.

Table 1 Prevalence and intensity of infection with gastrointestinal helminth parasites encountered in cattle slaughtered in Bauchi Central Abattoir

\begin{tabular}{lccccc}
\hline Helminth species & $\begin{array}{c}\text { Number of } \\
\text { infected }\end{array}$ & $\begin{array}{c}\text { \% } \\
\text { prevalence }\end{array}$ & $\begin{array}{c}\text { Intensity } \\
\text { Low (100-250 } \\
\mathbf{e p g})\end{array}$ & $\begin{array}{c}\text { Moderate (250- } \\
\mathbf{5 0 0} \mathbf{e p g})\end{array}$ & High (<500 epg) \\
\hline Trematode & & & & & \\
Fasciola gigantica & 47 & 15.7 & $13(27.6)$ & $16(34.0)$ & $18(38.2)$ \\
Schistosoma bovis & 18 & 06 & $9(50.0)$ & $8(44.4)$ & $1(1.0)$ \\
$\begin{array}{l}\text { Dicrocilium } \\
\text { dendriticum }\end{array}$ & 5 & 1.6 & $1(20.0)$ & $2(40.0)$ & $2(40.0)$ \\
\hline Cestodes & & & & & \\
Taenia saginata & 24 & 08 & $9(37.5)$ & $11(45.8)$ & $4(16.7)$ \\
Monezia expansa & 19 & 6.3 & $7(36.8)$ & $10(52.7)$ & $2(10.5)$ \\
Hymenolepis dimunuta & 6 & 2 & $2(33.3)$ & $3(50.0)$ & $1(33.3)$ \\
\hline Nematodes & & & & & \\
Haemonchus spp & 31 & 9.3 & $8(25.8)$ & $17(58.0)$ & $5(16.1)$ \\
Nematodirus spp & 18 & 06 & $5(27.7)$ & $9(50.0)$ & $2(22.2)$ \\
Ostertagia ostertagia & 15 & 5 & $9(60.0)$ & $4(26.6)$ & $2(13.3)$ \\
Toxocara spp & 10 & 3.3 & $3(30.0)$ & $3(30.0)$ & $4(7.1)$ \\
Ascaris spp & 10 & 3.3 & $2(20.0)$ & $5(50.0)$ & $3(30.0)$ \\
Trichuris spp & 3 & 01 & $1(33.3)$ & $1(33.3)$ & $1(33.3)$ \\
Strongyloides spp & 17 & 5.7 & $3(17.6)$ & $11(64.7)$ & $3(17.6)$ \\
Total & 223 & 74.3 & $74(33.1)$ & $100(44.8)$ & $49(21.9)$ \\
\hline
\end{tabular}

\subsection{Distribution of gastrointestinal helminths infection according to breed}

In terms of breed of the cattle (Table 2), white Fulani had the highest infection rate of $74.8 \%(182 / 234)$ followed by red Bororo $72.3 \%$ (34/47) and Sokoto gudali 70.0\% (7/10) respectively.

Table 2 Prevalence of gastrointestinal helminths according to breed

\begin{tabular}{lccc}
\hline Breed of Cattle & Number of Examined & Number of Infected & (\%) Infected \\
\hline White fulani & 243 & 182 & 74.8 \\
Sokoto gudali & 10 & 7 & 70.0 \\
Red Bororo & 47 & 34 & 72.3 \\
\hline Total & 300 & 223 & 74.3 \\
\hline
\end{tabular}

\subsection{Prevalence rate of gastrointestinal helminths based on breed of cattle examined}

The prevalence rate of gastrointestinal helminths based on breed of the cattle is shown in table 3. Fasciola gigantica was the highest specie and Trichuris was found to be last. 
Table 3 Prevalence rate of gastrointestinal helminths` based on breed of cattle examined

\begin{tabular}{llll}
\hline Helminth parasites & White fulani & Red Bororo & Sokoto Gudali \\
\hline Fasciola gigantica & $37(20.3)$ & $8(23.5)$ & $2(28.5)$ \\
Schistosoma bovis & $14(7.6)$ & $4(11.70)$ & $0(0.00)$ \\
Dicrocilium spp & $4(2.19)$ & $1(2.9)$ & $0(0.00)$ \\
Monezia expansa & $12(6.5)$ & $1(2.9)$ & $2(28.5)$ \\
Taenia saginata & $18(9.89)$ & $6(17.6)$ & $1(14.2)$ \\
Hymenolepis dimunuta & $4(2.19)$ & $2(5.8)$ & $0(0.0)$ \\
Haemonchus spp & $26(14.2)$ & $5(14.7)$ & $0(0.00)$ \\
Ostertagia ostertagia & $12(6.5)$ & $2(5.8)$ & $1(14.2)$ \\
Nematodirus spp & $16(8.7)$ & $2(5.8)$ & $0(0.00)$ \\
Toxocara spp & $7(3.8)$ & $2(5.8)$ & $1(14.2)$ \\
Ascaris spp & $9(4.9)$ & $1(2.9)$ & $0(0.0)$ \\
Trichuris spp & $3(1.0)$ & $0(0.0)$ & $0(0.00)$ \\
Strongyloides spp & $13(7.1)$ & $3(8.82)$ & $0(0.00)$ \\
\hline Total & $182(74.3)$ & $34(72.3)$ & $7(70.0)$ \\
\hline
\end{tabular}

\subsection{Distribution of gastrointestinal helminths according to age group}

Based on age group of the animals, (Table 4), the prevalence of gastro intestinal helminth were found to be $77.1(27 / 35)$ in Cattle less than 2 years, $74.2 \%(184 / 248)$ in young and 70\% (12/17) in adults.

Table 4 Prevalence of gastrointestinal helminths according to age group

\begin{tabular}{llll}
\hline Age Group(years) & Number of Examined & Number of Infected & (\%) Infected \\
\hline$<2$ Years & 35 & 27 & 77.7 \\
3-5 Years & 248 & 184 & 74.1 \\
$>$ 5 Years & 17 & 12 & 70.58 \\
\hline Total & 300 & 223 & 74.3 \\
\hline
\end{tabular}

\subsection{Distribution of gastrointestinal helminths according to gender}

The distribution of helminth parasites of slaughtered cattle by gender in the study area is shown in table 5. The result indicated that male cattle had higher prevalence of gastrointestinal helminth $39.6 \%(119 / 158)$ than their female counter part $34.5 \%(142 / 104)$.

Table 5 Prevalence of gastrointestinal helminths according to gender

\begin{tabular}{llll}
\hline Sex & Number of examined & Number of infected & (\%) Infected \\
\hline Male & 158 & 119 & 75.3 \\
Female & 142 & 104 & 73.2 \\
\hline Total & 300 & 223 & 74.3 \\
\hline
\end{tabular}




\subsection{Mixed infection with gastrointestinal helminths}

Out of 223 cattle examined, $167(55.67 \%)$ and 56(18.6\%) cattle were found to harbour single and mixed infections, respectively (Table 6).

Table 6 Mixed infection with gastrointestinal helminth in cattle

\begin{tabular}{|c|c|c|c|c|c|}
\hline Category & $\begin{array}{l}\text { Number of } \\
\text { examined }\end{array}$ & $\begin{array}{l}\text { Number of } \\
\text { infected }\end{array}$ & $\begin{array}{l}\text { Single } \\
\text { infection }\end{array}$ & Mixed infection & $\begin{array}{l}\text { Number of } \\
\text { infected }\end{array}$ \\
\hline \multicolumn{6}{|l|}{ Breed } \\
\hline White Fulani & 243 & 182 & 137 & $\begin{array}{l}\text { Monezia }+ \text { Nematodirus }+ \text { Fasciola } \\
\text { Ascaris }+ \text { Fasciola } \\
\text { Fasciola }+ \text { Haemonchus }+ \text { Taenia }\end{array}$ & $\begin{array}{l}10 \\
17 \\
18\end{array}$ \\
\hline Sokoto Gudali & 10 & 7 & 0 & Nil & 00 \\
\hline Red Bororo & 47 & 34 & 23 & $\begin{array}{l}\text { Dicrocilium }+ \text { Fasciola } \\
\text { Haemonchus }+ \text { Ostertagia }\end{array}$ & $\begin{array}{l}06 \\
05\end{array}$ \\
\hline Total & 300 & 223 & 167 & & 56 \\
\hline \multicolumn{6}{|l|}{ Sex } \\
\hline Male & 158 & 119 & 90 & $\begin{array}{l}\text { Ascaris }+ \text { Fasciola } \\
\text { Haemonchus }+ \text { Nematodirus }\end{array}$ & $\begin{array}{l}16 \\
13\end{array}$ \\
\hline Female & 142 & 104 & 77 & $\begin{array}{l}\text { Fasciola }+ \text { Haemonchus+Taenia } \\
\text { Dicrocilium +Fasciola }\end{array}$ & $\begin{array}{l}12 \\
15\end{array}$ \\
\hline Total & 300 & 223 & 167 & & 56 \\
\hline \multicolumn{6}{|l|}{ Age } \\
\hline$<2$ years & 35 & 27 & 18 & $\begin{array}{l}\text { Fasciola+Taenia } \\
\text { Taxocara+Ostertagia }\end{array}$ & $\begin{array}{l}2 \\
3\end{array}$ \\
\hline $3-5$ years & 248 & 184 & 141 & $\begin{array}{l}\text { Monezia }+ \text { Nematodirus } \\
\text { Monezia }+ \text { Nematodirus }+ \text { Fasciola }\end{array}$ & $\begin{array}{l}2 \\
20\end{array}$ \\
\hline$>5$ years & 17 & 12 & 8 & $\begin{array}{l}\text { Haemonchus+Ostertagia } \\
\text { Ostertagia+ Haemonchus }\end{array}$ & $\begin{array}{l}23 \\
4\end{array}$ \\
\hline Total & 300 & 223 & 167 & & 56 \\
\hline
\end{tabular}

The result of the study clearly indicates a high prevalence of gastrointestinal helminths in cattle slaughtered in Bauchi central abattoir, Bauchi State Nigeria. The study revealed that $74.3 \%$ of the sampled animals within the period were infected with either one or more species of parasitic helminths. These corresponds with findings of [19] who found as high as $62.1 \%$ prevalence rate of helminths in Port Harcourt, South-South, Nigeria and in Umuahia South Local Government Area, Abia State, Nigeria. However, the findings of [20] and [21] indicated a lower prevalence of 34.9\% in Wudil local government area of Kano and among the cattle slaughtered at Wukari abattoir, Taraba State, Nigeria. In contrast, a very high prevalence rate of $82.24 \%$ of intestinal parasite in cattle slaughtered in Aba was reported by [22] which could probably be due to the most favourable environmental condition for the development of larvae. Also, poor management of cattle such as poor grazing practices, infrequent transfer of animals from the holding place and watering of animals from natural pool during the rainy season always affected the animals which can invariably give room for high prevalence of intestinal helminths. This was in line with findings of [23] who reported that Cestodes and Nematoda are the major cause of morbidity in young cattle and ruminants in Nigeria. Again, the helminths identified in this study were similar to those identified by [24]. Regarding the intensity of helminth infection, the current study showed high percentage in moderate (44.8\%), low (33.1\%) and lower percentage in high infection (21.9\%). The reason for the majority of the animals showed moderate and low infection might be associated with development of immunity causing lower worm fecundity in adult animals. In addition, single infections were found to be more prevalent in comparison to mixed infections in this study. Mixed infection was characterized by the presence of two or more helminths. The phenomenon of mixed infection has been suggested to be an important cause of morbidity and reduced production in livestock [25]. Furthermore, the immune-suppression of the host immune system by mixed infections increases host susceptibility to other diseases or parasites [26]. Out of 300 samples examined 167(55.67\%) had single and 56 $(18.67 \%)$ had mixed infection with different helminths species. 


\section{Conclusion}

This study indicates that cattle slaughtered at Bauchi central abattoir harbor a wide variety of intestinal helminth parasites. The overall prevalence and the prevalence of the different types of parasites of cattle recorded are high enough to limit and constraint cattle production of the area. There could still be improvement in the health care of animals if animal rearers have sound knowledge of infections, treatment and control measures incorporated with effective management techniques.

\section{Compliance with ethical standards}

\section{Acknowledgments}

We wish to thank laboratory staffs of Department of Biological Sciences for their contribution to the success of this research.

\section{Disclosure of conflict of interest}

There's no what so ever any conflict of interest we are giving the outfit full right to publication of this work.

\section{References}

[1] Okoli IC, Enyinnia NC, Elijah AG, Omede AA and Unamba-Opara CI. (2012). Animal reproductive management practices of Fulani pastoralists in the humid rain Forest of Imo State, Nigeria. Journal of Animal Science Advances, 2(2), 221-225.

[2] Roger B. (1999). Traditional livestock breeds: geographical distribution and dynamics in relation to the ecology of West Africa. Overseas development institution Portland house stag place London, 19-61.

[3] Adedipe OD, Uwalaka EC, Akinseye VO, Adediran OA and Cadmus SI. (2014). Gastrointestinal helminths in slaughtered cattle in Ibadan, south-Western Nigeria. Journal of veterinary medicine.

[4] Bolajoko MB, Moses GD, Gambari-Bolajoko KO, Ifende VI, Emenna P and Bala A. (2011). Participatory rural appraisal of livestock diseases among the Fulani community of the Barkin Ladi Local Government Area, Plateau State, Nigeria. Journal of Veterinary Medicine and Animal Health, 3(1), 11-13.

[5] Hesterberg UW, Bagnall R, Perrett K, Bosch B, Horner R and Gummow B. (2008). A serological prevalence survey of Brucella abortus in cattle of rural communities in the province of KwaZulu-Natal, South Africa. Journal of the South African Veterinary Association, 79(1), 15-18.

[6] Maina JA. (1986). Animal health in sub humid Nigeria. In: Livestock Systems Research in Nigeria's Sub humid Zone. Proceedings of the second ILCA/NAPRI symposium held in Kaduna/ Nigeria, 29 October - 2 November 1984.

[7] Kudi AC, Bray MP, Niba AT and Kalla DJ. (2009). Mastitis causing pathogens within the dairy cattle environment. International Journal of Biology, 1(1), 3.

[8] Hansen J and Perry B. (1994). The epidemiology, diagnosis and control of helminth parasites of ruminants. A handbook.

[9] Anon JB. (2005). Current management of acute bacterial rhinosinusitis and the role of moxifloxacin. Clinical Infectious Diseases, 41(2), 167-176.

[10] JacquietP, Cabaret J, Thiam E and Cheikh D. (1998). Host range and the maintenance of Haemonchus spp. in an adverse arid climate. International Journal for Parasitology, 28(2), 253-261.

[11] Eysker M. (1997). Some aspects of inhibited development of trichostrongylids in ruminants. Veterinary Parasitology, 72(3-4), 265-283.

[12] Yahaya A and Tyav YB. (2014). A survey of gastrointestinal parasitic helminths of bovine slaughtered in abattoir, Wudil Local Government Area, Kano state, Nigeria. Greener Journal of Biological Sciences, 4(4), 128-134.

[13] Babagana M, Gimba B and Yusuf I. (2016). Introducing probabilistic models for redundant system reliability. Operations Research and Decisions, 26(1), 5-18. 
[14] Cheesbrough M. (1999). District laboratory practice in tropical countries part 1. Low price edition, Cambridge university press, Cambridge, 196-198,

[15] Ballweber LR. (2001). Practical veterinarian. Veterinary parasitology. In: Messonnier SP (Ed). Butter worth Heine Mann publication, USA.

[16] Soulsby EJL. (1982). Helminthes, arthropod and protozoan of domesticated animals. $7^{\text {th }}$ edition, Bailliere Tindall: London. UK, 809-810.

[17] Urquhart GM, Armour J, Duncan JL, Dunn AM and Jennings FW. (1996). Veterinary Parasitology, $2^{\text {nd }}$ edition, Blackwell Science, 28.

[18] Smith RL. (1976). Male brooding behavior of the water bug Abedusherberti (Hemiptera: Belostomatidae). Annals of the Entomological Society of America, 69(4), 740-747.

[19] Owhoeli O, Elele K and Gboeloh LB. (2014). Prevalence of gastrointestinal helminths in exotic and indigenous goats slaughtered in selected Abattoirs in Port Harcourt, South-South, Nigeria. Chinese Journal of Biology, 8.

[20] Yahaya A and Tyav YB. (2014). A survey of gastrointestinal parasitic helminths of bovine slaughtered in abattoir, Wudil Local Government Area, Kano state, Nigeria. Greener Journal of Biological Sciences, 4(4), 128-134.

[21] ShittaK. (2013). Gastro-intestinal helminthes of slaughtered cattle at Wukari Abattoir Taraba State, NorthEastern Nigeria. International Journal of Infectious Diseases, 15-18.

[22] Okike-Osisiogu FU, Arinze AG and Ekaiko MU. (2016). Prevalence of intestinal parasite in cattle slaughtered in Aba.

[23] Fabiyi JP. (1987). Production losses and control of helminths in ruminants of tropical regions. International Journal for Parasitology, 17(2), 435-442.

[24] Edosomwan EU and Shoyemi 00. (2012). Prevalence of gastrointestinal helminth parasites of cattle and goats slaughtered at abattoirs in Benin City, Nigeria. African Scientist, 13(2), 109-114.

[25] Kumsa B, Tadesse T, Sari T, Duguma R and Hussen B. (2011). Helminths of sheep and goats in Central Oromia (Ethiopia) during the dry season.Journal of Animal and Veterinary Advances, 10(14), 1845-1849.

[26] Wang CR, Qiu JH, Zhao JP, Xu LM, Yu WC and Zhu XQ. (2006). Prevalence of helminthes in adult dogs in Heilongjiang Province, the People's Republic of China, Parasitology Research,99(5), 627-630.

\section{How to cite this article}

Yuguda AU, Samaila AB and Panda SM. (2018). Gastrointestinal helminths of slaughtered cattle in Bauchi Central Abattoir, Bauchi State, Nigeria. GSC Biological and Pharmaceutical Sciences, 4(2), 58-65. 